Vol 2. No 1. Februari 2018

ISSN 2580-5029

\title{
PENGARUH LATIHAN RENANG TERATUR DAN LATIHAN RENANG TIDAK TERATUR TERHADAP KADAR TRIGLISERIDA PLASMA PADA Rattus norvegicus
}

\author{
Adi Wijayanto ${ }^{*}$ \\ 1Fakultas Tarbiyah dan Ilmu Keguruan - Insitut Agama Islam Negeri (IAIN) Tulungagung, \\ Indonesia \\ *Email: wijayantoadi@yahoo.com
}

\begin{abstract}
Triglycerides are source of energy in the body, but triglyceride deposits that exceed the threshold will cause health problems, so triglycerides should be lowered to normal. The reduction of triglycerides can be done through physical activity, therefore this study aims to reveal the effect of regular swimming exercises and irregular exercises against triglyceride levels. This research is an experimental research using The Post Test Only Control Group Design design. Subjects of the study were male of Rattus Norvegicus Wistar, 39 subjects was divided into 3 groups with Matched Subject Design technique, which consisted of 2 groups of treatment that is regular and irregular group, and control group. The exercise program was given a swimming with a 3\% weight of body weight and was tied $5 \mathrm{~cm}$ from the tip of the tail which was performed 3 times per week consistently for regular exercise and 0 to 5 times per week inconsistently for irregular exercise for 12 weeks, While the control group was not given training. In the last week before the blood was taken, the first three groups were given swimming treatment exercises. Based on the results of the anava test, there was a significant difference $(P<0.05)$ in the reduction of triglyceride levels among white mice who were given regular exercise with irregular exercise. These results suggest that regular exercise has a better impact on triglyceride reduction than irregular exercise, due to the higher adaptation process of regular exercise.
\end{abstract}

Keywords: regular exercise, irregular exercise, triglycerides.

\begin{abstract}
ABSTRAK
Trigliserida merupakan salah satu sumber energi yang ada dalam tubuh, namun timbunan trigliserida yang melebihi ambang batas akan menyebabkan masalah kesehatan, oleh sebab itu trigliserida harus diturunkan sampai kondisi normal. Penurunan trigliserida dapat dilakukan melalui aktivitas fisik, penelitian ini bertujuan untuk mengungkapkan pengaruh latihan renang teratur dan latihan renang tidak teratur terhadap kadar trigliserida. Penelitian ini merupakan penelitian eksperimental dengan rancangan The Post Test Only Control Group Design. Subyek penelitian adalah binatang coba tikus putih berkelamin jantan dari jenis Rattus Norvegicus Wistar berjumlah 39 yang dibagi menjadi 3 kelompok dengan teknik Matched Subject Design, yang terdiri 2 kelompok perlakuan yaitu kelompok teratur dan tidak teratur, serta kelompok kontrol. Program latihan berupa renang dengan beban 3\% dari berat badan dan diikatkan $5 \mathrm{~cm}$ dari ujung ekor, dilakukan 3 kali perminggu secara konsisten bagi latihan teratur dan $0 \mathrm{~s} / \mathrm{d} 5$ kali perminggu dengan tidak konsisten bagi latihan yang tidak teratur selama 12 minggu,
\end{abstract}


sedangkan kelompok kontrol tidak diberi latihan. Pada minggu terakhir sebelum pengambilan darah dilakukan. Berdasarkan hasil uji anava, terdapat perbedaan yang signifikan $(\mathrm{P}<0,05)$ pada penurunan kadar trigliserida antara tikus putih yang diberi latihan teratur dengan latihan tidak teratur. Hasil tersebut menunjukkan latihan teratur memberikan dampak yang lebih baik terhadap penurunan trigliserida dibanding latihan tidak teratur, hal tersebut disebabkan proses adaptasi latihan teratur lebih tinggi.

Kata Kunci: latihan teratur, latihan tidak teratur, trigliserida.

\section{PENDAHULUAN}

Morbiditas dan mortalitas penyakit aterosklerosis sampai saat ini masih tinggi, dan merupakan salah satu penyebab kematian utama (Bansal dkk, 2015:1). Tingginya aterosklerosis tersebut salah satunya disebabkan oleh gaya hidup masyarakat. Gaya hidup aktif telah berubah menjadi gaya hidup pasif. Dampak kemajuan teknologi mendorong masyarakat enggan melakukan aktivitas fisik, yang menjadi masalah dalam meningkatkan kualitas hidup. Aktivitas fisik yang teratur dan terukur yang mampu membuat kesehatan serta kebugaran tubuh yang semakin baik (Boone, 2017: 2). Sedangkan aktivitas fisik yang tidak teratur justru Akan menjadi pemicu timbulnya masalah kesehatan. Tetapi masalah latihan fisik tidak teratur terhadap tingkat kesehatan belum banyak mendapat perhatian.

Latihan teratur dan terukur menjadi harapan dalam upaya meningkatkan SDM (Sumber Daya Manusia). Namun kenyataan yang ada, tidak banyak masyarakat yang melakukan olahraga teratur, bahkan adanya kecenderungan menurunnya aktivitas fisik (Raistenskis dkk, 2016: 443). Latihan fisik yang tidak teratur berbahaya dan merugikan tubuh, sebab latihan fisik yang dilakukan secara tidak teratur akan dapat menurunkan derajat kesehatan tubuh seperti menurunnya elastisitas pembuluh darah. Sedangkan latihan fisik teratur dengan dosis tepat memberikan manfaat bagi program kesehatan, kebugaran, kinerja serta program rehabilitasi terhadap gangguan fungsi tubuh, latihan fisik teratur tersebut sangat dianjurkan sebab dapat menjadi modulator dalam pengelolaan penyakit jantung dan pembuluh darah (Hamidah, 2015: 429).

Latihan fisik renang menggunakan sistem energi dominan aerobik yang dilakukan secara teratur menurunkan resiko penyakit jantung koroner, cerebro-vaskular, tekanan darah tinggi, diabetes, obesitas dan osteoporosis (Elmagd, 2016: 22). Menurut Leelarugrayub (2005: 183) menunjukkan latihan tidak teratur dapat meningkatkan mobilisasi FFA (Free Faty Acid) dalam plasma darah sebesar $43 \%$ dibandingkan dengan yang teratur hanya sebesar $28 \%$.

Atas dasar permasalahan diatas, maka peneliti ingin membuktikan apakah latihan renang teratur berpengaruh terhadap kadar trigliserida plasma pada tikus putih?, apakah latihan renang tidak teratur berpengaruh 
terhadap kadar trigliserida plasma pada tikus putih? apakah terdapat perbedaan kadar trigliserida plasma latihan renang teratur dan latihan renang tidak teratur pada tikus putih?. Peneliti berharap penelitian tersebut dapat meningkatkan pengembangan ilmu olahraga dan menjadikan olahraga sebagai alternatif terapi, serta memberikan masukan bahwa olahraga teratur dapat meningkatkan sistem metabolisme dalam tubuh.

\section{METODE}

Penelitian ini adalah penelitian experimental laboratories, adapun rancangan yang digunakan adalah Randomized Subjects, Posttest-Only Control Group Design (Ary dkk, 2002:277). Sampel dalam penelitian ini adalah tikus dari jenis wistar berkelamin jantan dengan umur 3 bulan sejumlah 39 ekor yang diberi makan BRII secara ad libitum dengan berat badan awal 190 sampai 230 gram. Adapun besar sampel didasarkan pada perhitungan dengan menggunakan rumus Higgins \& Klinbaum diperoleh sampel minimal sejumlah 11 ekor tikus, peneliti dalam penelitian ini menggunakan sampel sejumlah 13 ekor setiap kelompok. Metode yang digunakan dalam pengukuran kadar trigliserida plasma darah adalah Colorimetric Enzymatic Test “GPO", sedangkan pengambilan darah dilakukan secara duplo melalui opticus orbitalis. Teknik analisis data menggunakan bantuan komputer dengan program SPSS, teknik analisis data yang digunakan dalam pelitian ini: Uji Anava dan
Uji Tukey HSD dengan taraf kepercayaan $\alpha=$ 0,05 .

Latihan teratur dalam penelitian ini adalah latihan renang dengan frekuensi 3 kali perminggu dengan prinsip overload pada setnya. Melalui percobaan, perlakuan terhadap 13 ekor tikus dengan diberi bentuk latihan aerobik dengan beban sebesar 3\% dari berat badan dan diikatkan $5 \mathrm{~cm}$ dari ujung ekornya.sedangkan latihan tidak teratur dalam penelitihan ini adalah latihan dalam bentuk renang dengan diberi bentuk latihan aerobik dengan beban sebesar 3\% berat badan dan diikatkan $5 \mathrm{~cm}$ dari ujung ekornya. Frekuensi pada latihan tidak teratur diberikan dengan tidak beraturan dan tidak konsisten dalam setiap minggunya (antara 0 sampai 5 kali latihan per minggu), set yang diberikan sebanyak 2 kali set dengan latihan dilakukan tanpa menggunakan prinsip overload, waktu latihan yang digunakan adalah 13 menit setiap setnya yang diambil berdasarkan $80 \%$ dari waktu maksimal berenang (Yunus, 2001:32).

\section{HASIL DAN PEMBAHASAN}

Untuk memperoleh ada tidaknya perbedaan pengaruh latihan latihan teratur dan tidak teratur terhadap kadar trigliserida pada tikus putih, maka Uji Anava perlu digunakan. Nilai Anava trigliserida, dapat dilihat pada tabel 1 .

Tabel 1. Uji Anava variabel Trigliserida Plasma dalam mg/dl 
Berdasarkan tabel 1, terdapat perbedaan bermakna antara kelompok latihan teratur, kelompok latihan tidak teratur, dan kelompok kontrol terhadap kadar trigliserida $(\mathrm{P}<0,05)$. Dengan bermaknanya nilai tersebut, maka uji lanjutan (Post Hoc) dengan uji Tukey HSD harus dilakukan untuk mengetahui seberapa besar perbedaan antar kelompok tersebut.

Uji Tukey HSD adalah uji yang digunakan untuk mengetahui berapa besar perbedaan antara masing-masing kelompok, berikut ini adalah nilai uji Tukey HSD dari Trigliserida yang dapat dilihat pada tabel 2 .

Tabel 2. Hasil Uji Tukey HSD variabel Trigliserida dalam satuan $\mathrm{mg} / \mathrm{dl}$

\begin{tabular}{|c|c|c|c|c|}
\hline \multirow{2}{*}{ Variabel } & \multirow{2}{*}{ Mean } & \multirow{2}{*}{ SD } & \multicolumn{2}{|c|}{ Anava } \\
\hline & & & $\mathbf{F}$ & $\mathbf{P}$ \\
\hline Teratur & 105,43 & 3,15 & \multirow{4}{*}{$\begin{array}{c}161 \\
, 79\end{array}$} & \multirow{4}{*}{0,0} \\
\hline Tidak & 123,95 & 3,17 & & \\
\hline Teratur & & & & \\
\hline Kontro & 132,58 & 4,39 & & \\
\hline
\end{tabular}

Berdasarkan tabel 2, dapat diketahui nilai dari uji Tukey HSD dari trigliserida antar kelompok sebagai berikut: perbedaan antara trigliserida kelompok latihan teratur dan kelompok latihan tidak teratur sangat bermakna $(\mathrm{P}<0,05)$. Perbedaan antara Trigliserida Kelompok latihan teratur dan kelompok kontrol sangat bermakna dengan $(\mathrm{P}<0,05)$. Perbedaan antara Trigliserida Kelompok latihan tidak teratur dan kelompok kontrol sangat bermakna $(\mathrm{P}<0,05)$.

\section{Latihan}

Latihan fisik telah lama dimanfaatkan dalam meningkatkan kualitas sumber daya manusia, tidak hanya ditujukan pada olahraga prestasi, tetapi juga untuk peningkatan kesehatan dan kesegaran jasmani yang harus berdasar pada kondisi sehat. Oleh sebab itu latihan fisik harus dilakukan dengan baik, dengan dosis yang tepat dan terukur. Latihan adalah suatu proses yang sistematis dan dilakukan secara berulang-ulang dengan beban semakin bertambah secara bertahap (Fox, 1993:69). Sedangkan menurut Brooks (1984:33) latihan adalah suatu aktivitas olahraga yang dilakukan secara sistematis dalam waktu yang lama ditingkatkan secara progresif dan individual yang mengarah kepada perubahan pada ciri-ciri fungsi fisiologis dan psikologis untuk mencapai sasaran yang telah ditentukan. Pada dasarnya latihan adalah memberikan tekanan fisik secara teratur sehingga meningkatkan kemampuan fisik didalam melakukan aktivitas.

Latihan fisik pada dasarnya adalah stressor bagi tubuh, oleh sebab itu latihan yang disarankan sebatas tubuh mampu untuk beradaptasi terhadap stress dari latihan tersebut. Demikian juga respon tubuh terhadap beban latihan juga sangat

\begin{tabular}{cccccc}
\hline Variabel & Mean & SD & Mean Beda & p \\
\cline { 1 - 3 } Teratur & 105,43 & 3,15 & \multirow{2}{*}{18,52} & \multirow{2}{*}{0,0} \\
\hline Tidak Teratur & 123,95 & 3,17 & & \multirow{2}{*}{27,15} & \multirow{2}{*}{0,0} \\
\hline Teratur & 105,42 & 3,15 & \\
\hline Kontrol & 132,58 & 4,39 & & \multirow{2}{*}{8,63} & \multirow{2}{*}{0,0} \\
\hline Tidak Teratur & 123,95 & 3,17 & \\
\cline { 1 - 2 } Kontrol & 132,58 & 4,39 & &
\end{tabular}


tergantung pada berat atau ringannya beban latihan yang diberikan. Beban latihan yang terlalu ringan tidak terjadi respon yang baik sehingga adaptasi sulit terjadi. Demikian pula sebaliknya jika beban yang diberikan terlalu berat, tubuh tidak mampu mentolerir beban, sehingga beban tersebut dianggap sebagai stressor, hal ini dapat menyebabkan terganggunya homeostasis sistem tubuh yang dapat berdampak negatif (Rushall dan Pyke, 1992: 3-5). Sebab dosis latihan yang berat dan tidak mampu ditolerir oleh tubuh, maka dapat menyebabkan kerusakan jaringan, timbulnya beberapa penyakit degeneratif dan meningkatnya peroksidasi lemak.

Aktivitas fisik diharapkan mampu mengembangkan kemampuan organik, neuromuskuler, intelektual dan emosional (Wijayanto, 2010:14). Pada dasarnya ada dua bentuk latihan fisik, yaitu latihan fisik aerobik dan latihan fisik aerobik dan anaerobik (Hottenrott et all, 2012:483). Pengertian latihan aerobik adalah latihan yang berlangsung lama, dengan intensitas rendah. Sistem energi aerobik pembentukan energi terjadi pada mitokondria, dimana pembentukan ATP memerlukan oksigen. Latihan aerobik memiliki efek terhadap kinerja jantung, pembuluh darah dan paru. Sedangkan latihan anaerobik artinya dalam pembentukan energi yang berupa ATP tidak membutuhkan oksigen, sehingga pembentukannya berlangsung dengan cepat dan bahan yang digunakan juga cepat habis. Sistem anaerobik terjadi pada sitoplasma
(Scott, 2005:32). Latihan fisik bentuk apapun kalau kita amati tidak memakai murni menggunakan salah satunya, akan tetapi terjadi keduanya, namun mungkin presentasenya yang berbeda.

\section{Latihan teratur}

Keteraturan latihan dapat dilihat dari frekuensinya yang teratur, frekuensi adalah jumlah ulangan latihan yang dilakukan dalam satu minggunya, antar frekuensi latihan terdapat istirahat sehingga menjamin tercapainya rasio optimal antara respon tubuh terhadap beban dan masa pemulihan. Latihan teratur merupakan latihan yang dilakukan dengan frekuensi yang teratur pada setiap minggunya (Abraham dan Chandroth, 2015: 68). Menurut Nealen (2016:349) latihan teratur adalah latihan yang dilakukan dengan mengatur jumlah frekuensi, intensitas, durasi dan set latihan sesuai dengan prinsip-prinsip dasar latihan yaitu overload. Sedangkan menurut Fogelholm (2006:15) yang dimaksud latihan teratur adalah latihan dengan frekuensi 3-5 perminggu dengan selang sehari. Sedangkan menurut Dick (2000:3) menyebutkan bahwa latihan teratur adalah latihan yang dilakukan dengan frekuensi 3 hingga 5 kali dalam setiap minggunya selama 30 menit/latihan dan meningkat hingga 2 jam pada akhir perlakuan pada treadmill, sedangkan intensitas latihan $21 \mathrm{~m} /$ menit yang ditingkatkan sampai $31 \mathrm{~m} /$ menit pada akhir latihan, dengan masa perlakuan selama 5 minggu pada tikus. 
Pada dasarnya pengertian dari latihan teratur adalah latihan fisik yang diberikan secara teratur dan konsisten dalam periode waktu tertentu, dari pernyataan tersebut peneliti mengacu pada teori latihan teratur yang dilakukan secara konsisten dan beraturan yang dilakukan antara 3 sampai 5 kali dalam setiap minggu, dengan intensitas dan waktu yang dinaikkan. Berdasarkan beberapa penelitian diatas, peneliti menggunakan pedoman latihan teratur dengan menggunakan frekuensi 3 kali dalam setiap minggu, dengan intensitas yang ditingkatkan berdasarkan repetisi, dengan durasi waktu yang tetap. Latihan teratur pertama kali menimbulkan beban pada tubuh "sterssor", akan tetapi beban tersebut direspon oleh tubuh melalui mekanisme umpan balik negatif dan bila dilakukan secara bertahap dan berkesinambungan akan memperbaiki kualitas fisiologi dari tingkat sistem.

\section{Latihan tidak teratur}

Latihan tidak teratur merupakan latihan fisik yang dilakukan dengan frekuensi tidak konsisten setiap minggunya antara $1 \mathrm{X}$ seminggu, $2 \mathrm{X}$ seminggu, $3 \mathrm{X}$ seminggu, $4 \mathrm{X}$ seminggu, $5 \mathrm{X}$ seminggu dan dilakukan secara acak (Hayyat dan Gopinath, 2016: 2022). Latihan tidak teratur dapat diartikan sebagai latihan yang dilakukan dengan menggunakan frekuensi yang berubah-ubah setiap minggunya. Sehingga definisi latihan tidak teratur secara umum adalah latihan fisik yang dilakukan secara tidak konsisten dan tidak beraturan dalam setiap minggunya yang dilakukan antara 0 sampai 5 kali. Sedangkan dalam penelitian ini intensitas dan waktu dikendalikan sama dengan latihan teratur.

\section{Sistem Energi}

Agar otot dapat melakukan fungsinya dengan baik maka diperlukan ATP (Adenosin TriPhosphate), tetapi ATP tidak hanya untuk kontraksi otot saja, ATP dibutuhkan untuk aktivitas semua sel. Bila diperlukan, ATP selalu dihidrolisis menjadi ADP (Adenosin Diphosphate), sekaligus melepaskan energi yang diperlukan oleh otot. Glikolisis aerobik merupakan pembentukan Adenosin Triphosphate (ATP) sebagai energi yang digunakan selama aktivitas fisik, dimana dalam proses glikolisis memecah glukosa menjadi dua asam piruvat. Glikolisis tergantung kepada: 1) konsentrasi enzim glikolisis seperti heksokinase, phospofruktokinase, dan piruvate kinase, 2) tingkat subtrat fruktose 1,6-diphosphate, dan 3) oksigen (McArdle, 2001:143). Tahap pertama glikolisis dengan merubah glukosa menjadi glukosa 6-fosfat, kemudian glukosa 6-fosfat dirombak menjadi fruktosa 6-fosfat, selanjutnya fruktosa 6-fosfat dirombak menjadi fruktosa 1,6-fosfat, setelah itu terjadi perubahan yang menghasilkan ATP yang berasal dari fruktosa 1,6-fosfat menjadi dua molekul 1,3-asam di fosfogliserat, setelah itu berturut-turut menjadi 3-asam fosfogliserat, 2-asam fosfogliserat, asam fosfoenolfirufat, 
selanjutnya asam fosfoenolfirufat menjadi asam piruvat (Guyton,1994:134). ATP yang terbentuk sejumlah 4 ATP, dengan demikian hasil akhir energi oleh seluruh proses glikolisis hanya 2 molekul ATP untuk masingmasing glukosa yang dipakai.

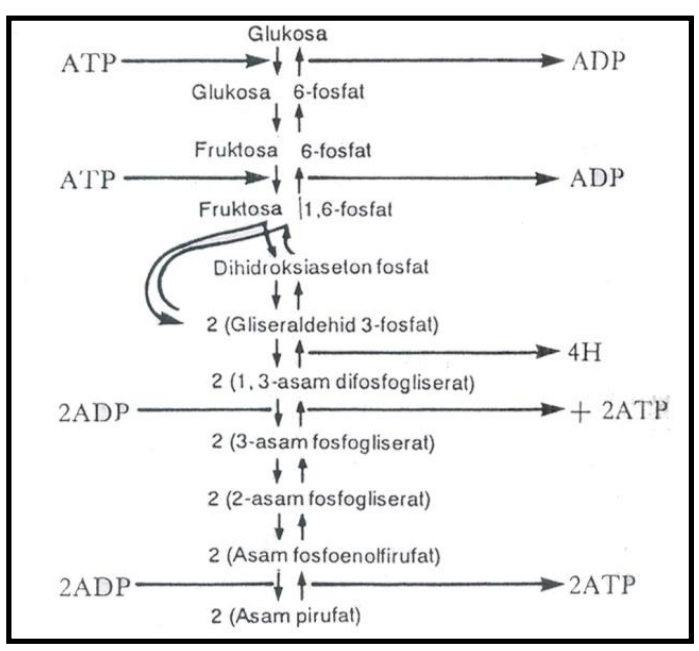

Gambar 1. Reaksi Kimia Glikolisis (Guyton,1994:134)

Pada siklus asam sitrat ini asetil-KoA (C2) yang telah dikonversikan bersama dengan oksaloasetat(C4) membentuk kembali asam sitrat (C6), isomer sitrat kemudian mengalami dekarboksilasi oksidatif menjadi senyawa $\alpha$-ketoglutarat ,senyawa ini kemudian mengalami dekarboksilasi oksidatif lagi menjadi suksinat yang kemudian diubah membentuk oksaloasetat kembali, dalam proses ini terbentuk dua karbon dioksida, dan terjadi empat reaksi oksidasi reduksi, dimana tiga ion hidrida (NADH) dipindahkan kepada molekul $\mathrm{NAD}^{+}$, sedangkan sepasang atom hidrogen (H2) dipindahkan kepada molekul flavin adenin dinukeotida (FAD) (Stryer, 2000:510).
Pembawa elektron ini akan menghasilkan 9 molekul ATP yang berasal dari 3 Molekul NADH, 1 molekul FAD yang menghasilkan 2 molekul ATP, dan 1 molekul ATP yang terbentuk dari Suksinil Ko-A. Pada siklus ini 1 molekul asetil-KoA menghasilkan 12 molekul ATP, sehingga dari siklus asam sitrat tersebut terbentuk 24 molekul ATP yang berasak dari 2 molekul asetil KoA.

\section{Trigliserida}

Trigliserida merupakan senyawa ester dari alkohol gliserida dan asam lemak. Trigliserida disintesa dari karbohidrat dalam hati. Selama pembentukan trigliserida hanya kira-kira $15 \%$ energi yang berasal dari glukosa dikeluarkan dalam bentuk panas, sedangkan $85 \%$ tetap ditransfer untuk disimpan sebagai trigliserida (Guyton, 1994:148). Dalam tubuh trigliserida berfungsi sebagai cadangan energi, karena trigliserida dalam jaringan adipose merupakan hasil penimbunan kelebihan energi dari makanan baik yang berasal dari karbohidrat maupun yang berasal dari lemak yang berlebih dirubah menjadi triasilgliserol. Trigliserida juga merupakan salah satu bagian pembentuk lipoprotein yang merupakan salah satu sumber energi paling utama (Supardan, 2001:37; Kimber,2003:1).

\section{Pembentukan trigliserida}

Lemak yang terdapat pada makanan sebagaian besar dalam bentuk lemak netral, yang dikenal juga sebagai trigliserida, dimana setiap molekulnya terdiri dari inti gliserol 
dan tiga asam lemak (Guyton, 1994:143).

Dalam saluran pencernaan sebagaian besar trigliserida dipecah menjadi mono gliserida dan asam lemak, sewaktu melewati epitel usus, kemudian disintesis lagi menjadi molekul trigliserida yang baru berkumpul dan bersama fosfolipid serta kolesterol terbentuk kilomikron yang mengalir di peredaran darah. Jaringan adiposa dan hati banyak enzim yang disebut lipase lipoprotein, enzim ini menyebabkan hidrolisis fosfolipid.

Langkah pertama dalam pembentukan trigliserida adalah konversi dari karbohidrat menjadi Asetil-KoA, ini terjadi selama pemecahan glukosa normal oleh sistem glikolisis (Murray,2003:178). Kombinasi Asam Lemak dengan $\alpha$-Gliserofosfat membentuk trigliserida, dimana sekali rantai asam lemak yang disintesis mengandung 14 sampai 18 atom karbon, mereka kemudian berikatan dengan gliserol untuk membentuk triglisrida. Mengenai gambaran umum dari pembentukan trigliserida dari glukosa dapat dilihat dari bagan berikut:

Gambar 2. Pembentukan trigliserida dari

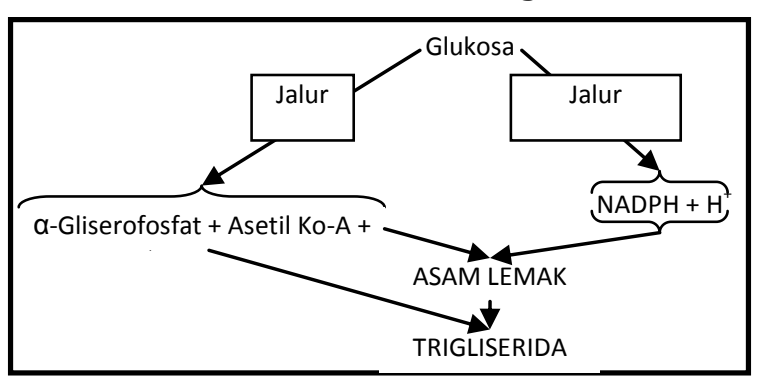

glukosa (Guyton,1994:148)
Pembentukan trigliserida dari protein, jika dalam tubuh protein sangat banyak atau melampaui ambang batas normal, maka asam amino tersebut akan di simpan dalam bentuk glikogen dan lemak. Asam amino deaminasi tertentu serupa dengan pemecahan yang dihasilkan dari metabolisme glukosa dan asam lemak, misalnya alanin deaminasi adalah asam piruvat (Guyton, 1994:160). Dari penjelasan tersebut sangat mungkin asam amino dikonversi menjadi asetil-KoA, yang dapat dipolimerisasikan menjadi asam lemak. Konversi dari asam amino menjadi asam lemak disebut dengan ketogenesis. Jika asam lemak dalam darah sangat banyak, maka seperti proses terdahulu akan disimpan di jaringan adiposa dalam bentuk trigliserida.

\section{Pembongkaran trigliserida}

Pembongkaran trigliserida merupakan salah satu pembentukan energi dengan syarat cukup oksigen agar pembongkaran tersebut dapat terjadi pada intensitas rendah sampai sedang dengan waktu yang cukup lama (Holloszy, 1998:1). Tahap pertama dalam penggunaan trigliserida untuk energi adalah hidrolisis dari senyawa ini menjadi 3 molekul asam lemak dan 1 molekul gliserol dan keduanya ditransport menuju jaringan, dimana asam lemak dan gliserol tersebut dapat dioksidasi untuk menghasilkan energi (Guyton, 1994:145). Asam lemak yang terbentuk tersebut akan ditransport menuju mitokondria, dimana ini merupakan proses 
katalis enzim yang memakai karnitin sebagai zat carrier. Setelah

memasuki

mitokondria asam lemak akan didegradasi dengan melepas 2 segmen karbon membentuk asetil-KoenzimA (asetil-KoA ). Proses ini disebut proses oksidasi beta untuk degradasi asam lemak.

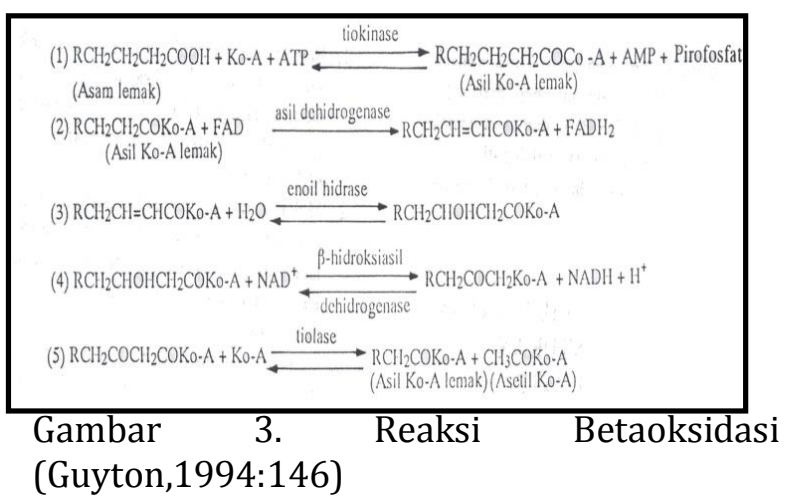

\section{Perubahan Fisiologis Tubuh akibat Latihan}

Latihan fisik atau olahraga akan berpotensial menimbulkan "stressor" apabila diberikan dalam dosis yang tidak tepat. Namun sterssor tersebut dapat dikondisikan dalam waktu tertentu, sehingga menjadi stimulator yang ditunjukkan dengan meningkatnya kualitas fisiologik (Plante dkk, 2001: 202). Untuk menyesuaikan dengan kebutuhan latihan maka mekanisme homeostasis berperan penting. Respon adaptasi tubuh terhadap beban latihan diwujudkan dengan fenomena respon "sindroma adaptasi umum" atau general adaptation syndrome (GAS) (Rushall dan Pyke, 1992: 27). Respon GAS tersebut meliputi 3 tahap yaitu tahap shok, tahap adaptasi dan tahap kelelahan.
Adapun perubahannya adalah sebagai berikut: a) perubahan otot, terjadinya pembesaran (hyperthropy), yang tergantung jenis otot dan macam latihannya diikuti dengan meningkatnya jumlah pembuluh kapiler, b) perubahan kapasitas aerobik yang meliputi peningkatan mioglobin, peningkatan oksidasi karbohidrat yang disertai dengan peningkatan jumlah mitokondria, diameter mitokondria dan peningkatan aktivitas enzim yang diperlukan dalam siklus krebs dan transport elektron, c) perubahan jantung yang meliputi peningkatan ukuran jantung, penebalan dinding ventrikel, dan juga diikuti dengan penurunan frekuensi denyut jantung, d) perubahan volume darah, miglobin dan kadar hemoglobin, e) perubahan paru, dengan kenaikan pernapasan per menit, f) kemampuan mentolerir kadar asam laktat dan daya tahan terhadap keasaman tubuh, g) peningkatan oksidasi lemak, yaitu peningkatan pelepasan asam lemak dari jaringan lemak dan peningkatan aktivitas enzim pemecah lemak, h) perubahan terhadap kolesterol, yaitu penurunan lemak tubuh (karena perubahan biokimia pada jaringan tubuh) dan diikuti perubahan lipoprotein plasma (perubahan kolesterol dan trigliserida).

\section{Pengaruh Latihan terhadap Enzim dan \\ Hormon}

Latihan daya tahan akan meningkatkan penggunaan energi dan oksigen sebagai bahan bakar, selama latihan 
hormon epiniprine dan norepiniprine dikeluarkan. Hormon epiniprine dan norepiniprine dikeluarkan oleh medula adrenal akibat rangsangan simpatis, kedua hormon tersebut secara langsung mengaktifkan lipase trigliserida peka hormon yang terdapat dalam jumlah besar dalam sel lemak, ini menyebabkan pemecahan yang sangat cepat terhadap trigliserida dan memobilisasi asam lemak (Mangine dkk, 2015: 132). Latihan akan merangsang hormon sensitivitas lipase untuk melarutkan lemak adalah molekul trigliserida menjadi tiga molekul atau asam lemak bebas dan satu molekul gliserol, faktor utama rangsangan tersebut adalah peningkatan konsentrasi plasma epiniprine yang mengaktifkan $\beta$ reseptor di adiposa. Jadi hal yang paling utama dalam perubahan trigliserida menjadi asam lemak adalah peningkatan kadar epiniprine yang akan menyebabkan meningkatnya pula lipase peka hormon yang terdapat pada jaringan adiposa.

\section{Pengaruh Latihan terhadap Trigliserida}

Berdasarkan hasil uji Tukey HSD yang telah dilakukan pada kelompok latihan (teratur dan tidak teratur) dibanding dengan kelompok tidak diberi latihan (kontrol) terdapat perbedaan yang signifikan. Perbedaan tersebut dapat diketahui pula melalui selisih rata-rata kadar trigliserida pada kelompok latihan dan tidak diberi latihan, rata-rata pada kelompok latihan sebesar 105,4282 $\mathrm{mg} / \mathrm{dl}$ untuk latihan teratur dan 123,9491 mg/dl untuk latihan tidak teratur, sedangkan pada kelompok tidak diberi latihan sebesar 132,5791 mg/dl. Hal tersebut membuktikan bahwa latihan dapat memberikan efek pada penurunan kadar trigliserida diban-ding dengan yang tidak melakukan latihan. Penurunan trigliserida tersebut menunjukkan bahwa perlakuan yang diberikan menimbulkan adaptasi sehingga terjadi perubahan kapasitas fungsional tubuh.

Selama latihan, asam lemak yang digunakan untuk energi berasal dari trigliserida yang tersimpan dalam otot dan depot lemak seluruh tubuh maupun yang bersikulasi dalam darah. Latihan dapat meningkatkan aktivitas enzim lipase pada otot dan jaringan adipose, sehingga terjadi pemecahan lipoprotein, yang menyebabkan penurunan trigliserida plasma. Latihan daya tahan akan meningkatkan kemampuan otot untuk mengambil dan mengoksidasi asam lemak selama latihan dan mengaktifkan enzim-enzim lipoprotein lipase, sedangkan lipoprotein lipase berfungsi untuk memisahkan asam lemak dari molekul lipoprotein. Setelah terjadi pemisahan maka asam lemak menyebar ke mitokondria untuk memproduksi energi melalui $\beta$-oksidasi. Asam lemak melewati mitokondria diperlukan zat perantara yang disebut sebagai zat carier, zat tersebut adalah karitin yang berfungsi membawa asam lemak untuk melakukan proses oksidasi di mitokondria. 
Menurut Pourvaghar (2011:58) menyebutkan bahwa latihan teratur dapat meningkatkan penyediaan trigliserida otot. Hal tersebut diperkuat oleh penelitian Hurley (1986:1) bahwa orang yang telatih penggunaan trigliserida otot lebih tinggi dibanding yang tidak terlatih. Pada latihan aerobik yang teratur dapat meningkatkan jumlah dan ukuran mitokondria yang disebabkan adanya adaptasi tubuh akibat latihan, sehingga metabolisme akan menjadi lebih efektif (Coyle, 1995:4; Mulla, 2000: 1-2). Energi yang digunakan saat pertama kali latihan daya tahan dengan durasi yang lama adalah ATP-PC, setelah glikogen otot persediaanya mulai menipis, maka sumber energi yang banyak dipakai adalah lemak (Hawley,1998:1; Dyck, 2000:2).

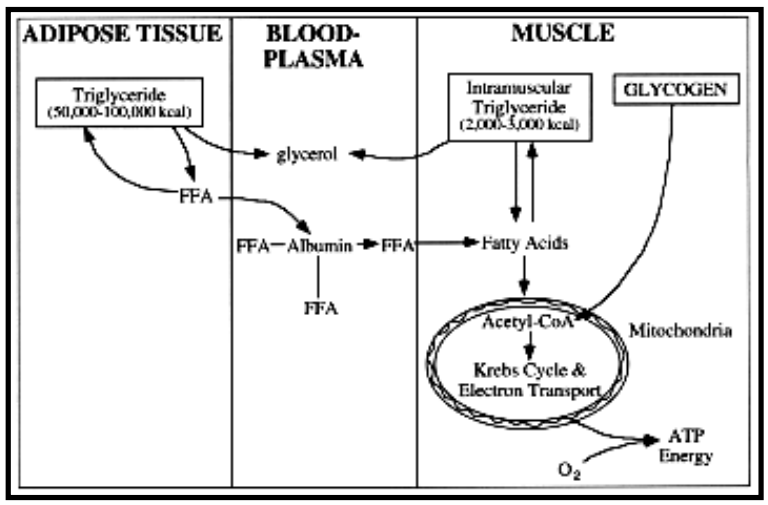

Gambar 4. Persediaan trigliserida

(Coyle,1995:2)

Sarat pembongkaran lemak adalah cukup oksigen dengan waktu latihan yang lama, dimana lemak yang pertama kali mengalami lipolisis adalah lemak dalam bentuk trigliserida endogen yang berada pada jaringan otot. Setelah persediaan trigliserida endogen dalam otot mulai menipis, maka sel akan mengambil trigliserida yang ada dalam pembuluh darah yang sudah dalam bentuk asam lemak bebas, dimana asam lemak bebas yang ada pada plasma darah berasal dari jaringan adipose dan hati, kemudian asam lemak bebas akan masuk dalam otot untuk dijadikan sebagai sumber energi (Coyle, 1995:2; Horowitz,2000:559; Hall, 2002:1-3).

Pada saat latihan, asam lemak yang digunakan untuk energi kontraksi otot terutama berasal dari trigliserida yang tersimpan di otot dan depot lemak seluruh tubuh, maupun bersirkulasi dalam darah, enzim lipase bertanggung jawab untuk pemecahan asam lemak dari trigliserida, yang diaktivasi oleh hormon epineprin dan norepineprin (Kushartanti,1996:60-61). Jadi Program latihan daya tahan dengan waktu yang lama akan memperbaiki metabolisme lemak dengan jalan meningkatkan kemampuan otot untuk mengambil dan mengoksidasi asam lemak bebas selama latihan yang diaktifkan oleh enzim lipoprotein lipase, dimana enzim tersebut diaktifkan oleh hormone epineprin dan norepineprin.

Latihan yang dilakukan dalam waktu yang berkesinambungan akan dapat meningkatkan adaptasi pada mitokondria dalam sel dengan meningkatnya jumlah dan ukuran dari mitokondria yang menyebabkan kemampuan lipolisis trigliserida endogen dalam otot meningkat (Coyle, 1995:4; Helge, 
2003:1, Holloszy,1998:5). Sedangkan latihan dapat meningkatkan penggunaan asam lemak yang berasal dari penggunaan trigliserida endogen (Goodpaster, 2001:5755). Berdasarkan beberapa pendapat, maka dapat diambil suatu garis besar bahwa saat terjadi penipisan sumber energi dalam bentuk glikogen otot, maka penggunaan lemak sebagai sumber energi mulai dilakukan, maka pertama kali yang terjadi adalah dengan pemakaian trigliserida endogen yang ada pada otot yang dirombak terlebih dahulu menjadi asam lemak bebas oleh enzim lipase, setelah dirombak maka akan diteruskan ke mitokondria untuk menjalani beta oksidasi yang menghasilkan energi yang digunakan dalam latihan.

Pengaktifan lipoprotein lipase juga dipengaruhi oleh pengaktifan epinephrine dan norepinephrine, serta glukagon (Moneva, 2010: 93). Tetapi pengaktifan lipoprotein lipase dihambat oleh insulin, hal tersebut juga dinyatakan oleh Helge dan Dela (2003:1885) bahwa latihan daya tahan sangat berpengaruh terhadap peningkatan sensitifitas lipase, tetapi mempunyai hubungan yang bersebrangan dengan insulin yang bersifat menghambat sensitifitas lipase. Pada kelompok yang tidak diberi latihan sama sekali, pembongkaran lemak sedikit terjadi, hal tersebut dikarenakan penggunaan energi yang digunakan berasal dari glikogen sudah cukup dalam penyediaan energinya, serta rendahnya tingkat sensitivitas lipase untuk lipolosis juga rendah.

\section{Pengaruh Latihan Teratur dan Latihan} Tidak Teratur terhadap Trigliserida

Berdasarkan hasil uji Tukey HSD yang telah dilakukan pada kelompok latihan teratur dibanding dengan kelompok latihan tidak teratur terdapat perbedaan yang signifikan. Perbedaan tersebut dapat diketahui pula melalui selisih rata-rata kadar trigliserida pada kelompok terlatih dan tidak terlatih. Rata-rata pada kelompok latihan teratur $106,1575 \mathrm{mg} / \mathrm{dl}$, dan pada kelompok latihan tidak teratur sebesar $124,3783 \mathrm{mg} / \mathrm{dl}$. Hal tersebut membuktikan bahwa latihan yang dilakukan 12 minggu secara teratur dapat memberikan efek pada penurunan kadar trigliserida lebih besar dibanding dengan yang melakukan latihan secara tidak teratur. Menurut Aslan dkk (1998:411) bahwa latihan yang dilakukan secara teratur akan menyebabkan meningkatnya sistem antioksidan dan menurunkan peroksidasi lemak. Menurunnnya peroksidasi lemak akan berakibat meningkatnya lipolisis, sehingga trigliserida mengalami penurunan yang cukup signifikan. Latihan dapat menimbulkan perubahan fisiologi pada hampir semua sistem tubuh, perubahan yang dihasilkan akan menyebabkan proses adaptasi fisiologi terhadap dosis latihan, sehingga dapat terjadi peningkatan kemampuan fungsional tubuh. Latihan yang diberikan secara teratur akan dapat berakibat terjadinya adaptasi pada tubuh, dimana adaptasi adalah perubahan struktur atau fungsi organ-organ tubuh yang sifatnya lebih menetap (Lamb, 1984:11-15). 
Latihan yang diberikan secara teratur akan memperbaiki metabolisme lemak dengan jalur meningkatkan kemampuan otot untuk mengambil dan mengoksidasi asam lemak bebas selama latihan dan juga meningkatkan enzim lipoprotein lipase (Helge dan Dela, 2003:1). Latihan yang dilakukan dalam waktu yang berkesinambungan dapat meningkatkan adaptasi pada mitokondria dalam sel dengan meningkatnya jumlah dan ukuran dari mitokondria yang menyebabkan kemampuan lipolisis trigliserida endogen dalam otot meningkat, peningkatan kemampuan lipolisis tersebut tidak terlepas dari peranan hormon epinephrine dan norepinephrine yang dikeluarkan oleh medula adrenal akibat rangsangan simpatis (Coyle dan Hill, 1995:2). Kedua hormon tersebut secara langsung mengaktifkan lipase trigliserida peka hormon yang terdapat dalam jumlah besar dalam sel lemak, ini menyebabkan pemecahan yang sangat cepat terhadap trigliserida dan memobilisasi asam lemak, proses lipolisis tersebut melalui beta oksidasi yang terjadi dalam mitokondria, setelah trigliserida endogen mulai menipis, maka energi banyak diambil dari simpanan trigliserida yang ada pada jaringan adiposa, Masuknya asam lemak ke dalam mitokondria untuk oksidasi, yang pertama kali dilakukan adalah mentransport mereka ke dalam mitokondria, ini adalah suatu proses katalis enzim yang memakai karitin sebagai sat carrier, setelah di dalam mitokondria, asam lemak berpisah dari karnitin dan kemudian dioksidasi didalam mitokondria untuk menjadi energi.

Perbedaan yang terjadi terhadap kadar trigliserida antara latihan teratur dan latihan tidak teratur disebabkan proses adaptasi yang kurang baik pada latihan tidak teratur dibanding latihan teratur. Latihan yang dilakukan tidak berkesinambungan akan dapat meningkatkan adaptasi pada mitokondria dalam sel, tetapi peningkatan tersebut tidak sebanyak pada latihan teratur. Pada latihan yang dilakukan dengan tidak teratur akan berpengaruh terhadap produksi radikal bebas yang lebih besar dibanding latihan yang dilakukan secara teratur.

\section{Pengaruh Latihan terhadap Radikal Bebas}

Radikal bebas merupakan atom atau sekelompok atom yang memiliki satu atau lebih elektron yang tidak berpasangan pada lintasan paling luar (Sarma, 2010:185). Radikal bebas tersebut sangat reaktif, tidak stabil dan biasanya muncul pada konsentrasi yang rendah. Radikal bebas ini dapat menginduksi reaksi berantai yang berjalan lambat pada kondisi normal tapi bisa berjalan lambat pada kondisi normal tapi bisa berjalan cepat atau terakselerasi jika ada rantai inisiator, misalnya ada radikal bebas yang lain (Robin, 1984:5). Peningkatan radikal bebas terjadi ketika konsumsi oksigen meningkat (peningkatan respirasi) dan disertai dengan proses reduksi yang dapat merangsang oksigen. 
Latihan secara teratur serta frekuensi dan intensitas yang tepat akan dapat membentuk antioksidan endogen yang dibentuk pada jantung, sehingga otot jantung lebih mampu menghadapi radikal bebas (Wuladnari, 2000:19-20). Dari proses oksidasi ini akan didapatkan hubungan antara produksi radikal bebas dan metabolisme tubuh, sirkulasi oksigen ke jaringan dan konsumsi oksigen (Bejma,1999:2; Aslan, 1998:1; Ji,1999:2).

Pada manusia radikal bebas terbanyak adalah radikal bebas oksigen sebagai hasil samping rantai pernapasan di mitokondria. Produksi radikal bebas yang melebihi normal akan menyebabkan terjadinya kerusakan jaringan. Melakukan latihan yang terlalu berat dengan waktu lama, atau melakukan latihan berat secara tiba-tiba akan menimbulkan adaptasi yang tidak sempurna, biasanya hasil dari keadaan seperti ini adalah kerusakan otot. Sedangkan latihan fisik yang diberikan secara tidak teratur dapat menimbulkan beberapa dampak kerugian pada tubuh. Latihan tidak teratur diduga tidak mampu meningkatkan antioksidan endogen karena kerusakan sel dalam sel otot jantung, sehingga tidak mampu mempertahankan kontraktilitas.

Saat berolahraga tubuh akan mengalami peningkatan kebutuhan oksigen sehingga produksi radikal bebas akan meningkat. Dengan meningkatnya jumlah radikal bebas tersebut akan berpengaruh terhadap peroksidasi lemak, serta lipolisis trigliserida yang ada dalam otot, dimana lipolisis tersebut terjadi dalam mitokondria, sehingga dengan terjadinya kerusakan mitokondria akan menyebabkan terganggunya proses lipolisis trigliserida pada sel tersebut, selain itu metabolisme trigliserida yang terjadi pada mitokindria akan terganggu, hal tersebut diakibatkan kurangnya oksigen sebagai sarat pembakaran trigliserida akibat radikal bebas yang disebabkan stress oksidasi.

\section{KESIMPULAN}

Berdasarkan hasil penelitian maka dapat disimpulkan bahwa latihan teratur dan tidak teratur berpengaruh terhadap penurunan trigliserida plasma pada tikus putih, latihan teratur memiliki pengaruh yang lebih bermakna terhadap penurunan trigliserida dibanding latihan tidak teratur, tetapi melakukan latihan lebih baik dibanding dengan tidak melakukan latihan sama sekali. Latihan teratur akan dapat meningkatkan kemampuan tubuh, baik ditinjau dari respon, adaptasi maupun pencegahan kerusakan jaringan sehingga dapat meningkatkan kesegaran jasmani dan kesehatan, dimana dengan latihan yang teratur tubuh pertama kali akan menanggapi sebagai respon sesaat, tetapi jika dilakukan secara berulang-ulang akan menjadi adaptasi pada tubuh, baik terhadap struktur tubuh maupun fungsi organ organ tubuh. Pada latihan teratur terjadi jawaban lambat/ adaptasi yang 
ditandai perubahan struktur atau fungsi organ-organ tubuh yang sifatnya lebih menetap, karena mengikuti atau sebagai akibat dari latihan fisik yang diberikan secara teratur dalam periode waktu tertentu.

Latihan yang dilakukan secara tidak teratur akan dapat merugikan terhadap tubuh, sebab kerusakan yang terjadi tidak bisa ditanggapi tubuh secara maksimal. Adaptasi pada latihan tidak teratur dimungkinkan tetap terjadi, akan tetapi tidak sebesar dan seefektif yang terjadi pada latihan teratur. Hal tersebut diakibatkan fungsi adaptasi yang menurun kembali jika tidak diberi latihan selama 48 jam atau lebih.

Untuk menurunkan trigliserida, maka disarankan melakukan latihan teratur setiap minggu. Mengingat keterbatasan peneliti, maka perlu dilakukan penelitian sejenis dengan menggunakan bentuk latihan yang berbeda dan menambah beberapa variabel, serta dalam melakukan penelitian yang menggunakan hewan coba, hendaknya ada hewan yang diperiksa dan dijadikan pretest.

\section{DAFTAR RUJUKAN}

Abraham, Joshy and Chandroth, Daliya Anoo. 2015. Impact of Regular Exercise Program for Depression in Adults. IOSR Journal of Nursing and Health Science (IOSR-JNHS) eISSN: 2320-1959. p-ISSN: 2320-1940 Volume 4, Issue 4 Ver. III (Jul. - Aug. 2015), PP 68-71

Ary, Donald., Jacobs, Lucy. Chester., Razavich, Asghar. 2002. Introduction to Research in Educations (6 ${ }^{\text {th }}$.). California: Wadsworth Thomson Learning.
Aslan, Reep., Sekeroglu, M.Ramazan., Tarakcioglu, Mehmet., Bayiroglu, Fahri dan Meral, Ismail. 1998. Effect of acute and Regular exercise on antioxidative enzymes, tissue damage markers and membrane lipid Peroxidation of Erythrocytes in Sedentary Students. Journal of Medical Science, Vol. 28:411-414

Bansal, Yogender Singh., Mandal, Shatrugan Prasad., Kumar, Senthil., Setia, Puneet. 2015. Prevalence of Atherosclerotic Coronary Stenosis in Asymptomatic North Indian Population: A Post-mortem Coronary Angiography Study. Journal of Clinical and Diagnostic Research. 2015 Sep, Vol-9(9): HC01-HC04

Bejma, J dan Ji, L.L. 1999. Aging and acute exercise enhance free radical generation in rat skeletal muscle. Journal of Applied Physiology, (Online), Vol. 87:465-470.

Brooks, G.A dan Fahey, T.D. 1984. Exercise Physiology: Human Bioenernetics and its Applications. New York: John Willey and Son.

Coyle, Edward.E. 1995. Fat Metabolism During Exercise. Journal of Sport Science Exchange, Vol 8, No. 6

Dick, Frank.W.1989. Sport Training Principles $\left(2^{\text {nd }}.\right)$. London: A\&C Black Ltd.

Dyck.D.J., Miskovic, D., Code, L., Luiken, J.J.F.P dan Bonen, A. 2000. Endurance Training increases FFA oxidation and reduces triacylglycerol utilization in contracting rat soleus. Am J Physiol Endocrinol Metab, Vol. 278, E778-E785

Elmagd, Mohammed Abou. 2016. Benefits, need and importance of daily exercise. International Journal of Physical Education, Sports and Health; 3(5): 22-27. P-ISSN: 2394-1685. E-ISSN: 2394-1693

Fogelholm, Mikael., Stallknecht, Bente \& Baak, Marleen Van. 2006. ECSS position statement: Exercise and obesity. European Journal of Sport Science, 6(1): 15/24. ISSN 1746-1391 print/ISSN 1536-7290 online \# 2006 European College of Sport Science DOI: $10.1080 / 17461390600563085$

Fox, Edward.L. 1993. Sport Physiology (2nd.). Columbus, Ohio: Ohio State University. 
Goodpaster, Bret.H., He, Jing., Watkins, Simon dan Kelley, David.E. 2001. Skeletal Muscle Lipid Content and Insulin Resistance: Evidence for a Paradox in Endurance-Trained Athletes. The Journal of Clinical Endocrinology \& Metabolism, Vol. 86(12):5755-5761

Guyton, Arthur.C. (Eds.). 1994. Buku Ajar Fisiologi Kedokteran. Edisi 7 bagian III. Jakarta: Penerbit Buku Kedokteran EGC.

Hall, G.Van., Saccetti,M., Radegran, G dan Saltin, B. 2002. Human skeletal muscle fatty acid and glycerol metabolism during rest, exercise and recovery. Journal of Physiology, Vol. 543.3, pp:1047-1058,

Hamidah, Zahra., Santoso, Putri Teesa Radhiyanti., Karyono, RM. Haryadi. 2015. Effect of Regular Exercise on Anxiety and SelfEsteem Level in College Students. Althea Medical Journal. 2015;2(3)

Hawley, John.A.1998. Fat Burning During Exercise: Can Ergogenics Change the Balance. The Physician and Sportmedicine, Vol. 26, No. 9

Hayyat, Faisal Suleh dan Gopinath, V. 2016. Impact of Random Exercise on Fasting Glucose of Type II Diabetics. Imperial Journal of Interdisciplinary Research (IJIR) Vol-2, Issue-12, 2016 ISSN: 2454-1362,

Helge, Jorn.W dan Dela, Flemming. 2003. Effect of Training on Muscle Triacylglycerol and Structural Lipids. Journal Diabetes Departemen of Medical Physiology, University of Copenhagen, Vol. 52:18811887.

Holloszy, John.O., Kohrt, Wendy.M dan Hansen, Polly.A. 1998. The Regulation of carbohydrate and fat metabolism during and after exercise. Departement of medicine, Washington university of Medicine, St Louis,

Horowitz, Jeffrey.F dan Klein, Samuel. 2000. Lipid Metabolism during endurance exercise. Journal Clinical Nutrition, Vol. 72, suppl: 558S-63S,

Hottenrott, Kuno., Ludyga, Sebastian and Schulze, Stephan. 2012. Effects of high intensity training and continuous endurance training on aerobic capacity and body composition in recreationally active runners. Journal of
Sports Science and Medicine (2012) 11, 483488

Ji, Li.Li. 1999. Antioxidants and Oxidative Stress in Exercise._Journal of the Society for Experimental Biology and Medicine, Vol. 222:283-292

Kushartanti, B.M.Wara. 1996. Pengaruh intensitas latihan fisik terhadap kadar glukosa, lipid dan insulin darah pada diabetes mellitus tidak tergantung insulin. Disertasi tidak diterbitkan. Surabaya: Program Pascasarjana Universitas Airlangga.

Lamb, David.R. 1984. Physiology of Exercise: Responses \& Adaptations (2 ${ }^{\text {nd }}$.). New York: Collier MacMilan Inc.

Leelarugrayub, Nuttakaan., Sutabhaha, Tharaporn., Pothongsunun, Prapas., and Chanarat, Nantaya. 2005. Exhaustive Exercise Test and Oxidative Stress Response in Athletic and Sedentary Subjects. CMU Chiang Mai University Journal (2005) Vol. 4(2)

Mangine, Gerald T., Hoffman, Jay R., Fukuda, David H., Stout, Jeffrey R., and Ratamess, Nicholas A. 2015. Improving Muscle Strength and Size: The Importance of Training Volume, Intensity, and Status. Journal Kinesiology 47(2015)2:131-138

McArdle, William.D, Katch, Frank.I dan Katch, Victor.L. 2001. Exercise Physiology: Energy, Nutrition, and Human Performance (5th ed.). Maryland: Lippicott Williams and Wilkins.

Moneva, P., Gudev, D., Ralcheva, S Popova., D, Abadjieva and Yanchev, I. 2010. Role of Glucagon in The Metabolic Response to Stress in Chickens. Bulgarian Journal of Agricultural Science, 16 (No 1) 2010, 91-98.

Mulla, Nariman.A.L., Simonsen, Lene dan Jens Bulow. 2000. Post-exercise adipose tissue and skeletal muscle lipid metabolism in humans: the effects of exercise intensity. The Journal of Physiology, Vol. 524.3, pp 919-928,

Murray, Robert.K., Granner, Daryl.K., Mayes, Peter.A dan Rodwell, Victor.W. 2003. Biokimia Harper. Jakarta: Penerbit buku Kedokteran EGC.

Nealen, Paul M. 2016. Exercise And Lifestyle Predictors Of Resting Heart Rate In Healthy 
Biotropic 2018. 2 (1): $24-40$

Pengaruh Latihan Renang Teratur Dan Latihan Renang Tidak Teratur Terhadap Kadar Trigliserida Plasma Pada rattus norvegicus Wistar

young adults. Journal of Human Sport \& Exercise. ISSN 1988-5202. of Alicante Volume $\quad 11 \quad$ Issue 3016 |Doi:10.14198/Jhse.2016.113.02.

Plante, Thomas G., Coscarelli, Laura dan Maire Ford. 2001. Does Exercising with Another Enhance the Stress-Reducing Benefits of Exercise?. International Journal of Stress Management, Vol. 8, No. 3, 2001

Pourvaghar, Mohammad Javad. 2011. The Effect of Eight Weeks of Aerobic Running on The Lipoproteins and Lipid Concentration Factors in Male Athletes. Journal of Optoelectronics and Biomedical Materials, Vol. 3 Issue 3, July - September 2011 p. 57 61

Raistenskis, Juozas., Sidlauskiene, Aurelija., Strukcinskiene, Birute., Baysal, Serpil Uğur., Buckus, Raimondas. 2016. Physical activity and physical fitness in obese, overweight, and normal-weight children. Turkish Journal of Medical Sciences Turk J Med Sci (2016) 46: 443-450

Robbins, Stanlell., Ramzi S.C dan Vinay, K. 1984. Cellular Injury and Adaptation, Pathologic Basis of Disease ( $3^{\text {rd }}$ ed.). Philadelphia: WB Saunders Company.

Rushal, B.S dan Pyke. 1992. Training for Sport and Fitness. Meulbourne, Australia: The MacMilan Co.

Sarma, Abheri Das., Mallick, Anisur Rahaman and Ghosh, A. K.. 2010. Free Radicals and Their Role in Different Clinical Conditions. International Journal of Pharma Sciences and Research (IJPSR) Vol.1(3), 2010, 185192

Scott, Christopher. 2005. Misconceptions about Aerobic and Anaerobic Energy Expenditure. Journal of the International Society of Sports Nutrition. 2(2): 32-37, 2005

Wijayanto, Adi. 2010. Pengaruh metode pembelajaran dan persepsikinestetik terhadap hasil belajar lay up bolabasket. Paradigma Jurnal Ilmiah Pendidikan Teori dan Penelitian. Vol. XV, nomor 29 tahun 2010.

Wulandari, Nuning. 2000. Pengaruh Latihan dengan Treadmill terhadap Kontraktilitas otot jantung tikus (Rattus Norvegicus) pada Perlakuan Iskemia Reperfusi dengan
Preparasi Langendorf. Skripsi tidak diterbitkan. Malang: Laboratorium Farmakologi, Fakultas Kedokteran Universitas Brawijaya.

Yunus, Moch. 2001. Pengaruh Antioksidan Vitamin $C$ terhadap MDA Eritrosit Tikus Wistar Akibat Latihan Aerobik. Malang: Lab. Jurnal IK dan $\mathrm{Pe}$ 